\title{
Extrinsic Motivation With Learning Achievements Student Of Nursing
}

\author{
Fitrah Suciah ${ }^{1}$, Hamdana ${ }^{2}$, Fatmawati ${ }^{3}$ \\ S1 Nursing Study Program, Stikes Panrita Husada Bulukumba, Indonesia1 \\ Departemen Surgical Medical Nursing, Stikes Panrita Husada Bulukumba, Indonesia ${ }^{2}$ \\ Departemen Mental Health Nursing, Stikes Panrita Husada Bulukumba ,Indonesia ${ }^{3}$
}

Corresponding Autor : fitrahsuciaha126@gmail.com

\begin{abstract}
It must be stressed, that motivation is related to a goal. Learning outcomes will be optimal if there is motivation. Seeing the phenomena there are still many nursing students of Panrita Husada Bulukumba who obtained the final GPA while in the low category. Not only that, but there are also some complaints during the lecture process that are obtained from interviews with students who can interfere with the learning process. This study aims to determine the relationship of extrinsic motivation in terms of the role of the lecturer, the condition of the learning environment, the learning methods used by the lecturer, facilities, and infrastructure with the learning achievements of nursing students. This research uses a quantitative analytic design with a crosssectional approach. The population in this study was 297 respondents. The number of samples was 100 respondents using a simple random sampling technique. The data collection method is done by using bivariate questionnaire sheets using Fisher's exact test. The results showed that there was a significant difference in proportion or relationship between the role of lecturers and learning achievement $(p=0.003)$, learning environment conditions and learning achievement ( $p$ $=0.043)$, lecturer learning methods and learning achievement $(\mathrm{p}=0.029)$, facilities and infrastructure with learning achievement $(p=0.040)$. The conclusion is that there is a significant relationship between extrinsic motivation (the role of the lecturer, the condition of the learning environment, the lecturer learning method, and learning support facilities or facilities and infrastructure) with the learning achievement of the nursing student Panrita Husda Bulukumba.
\end{abstract}

Keywords: Extrinsic Motivation, Learning Achievement

\section{INTRODUCTION}

Education is a conscious effort to grow the potential of human resources (HR) through teaching activities. There are two interrelated educational concepts, namely learning and learning (Nursalam, 2008). In teaching and learning activities the role of motivation is very necessary. Motivation is related to a goal, learning outcomes will be optimal if there is motivation. Conversely, if the learning activities do not go through a process based on good motives, they will produce false, non-authentic, and long-lasting learning outcomes. Motivation can function as a business driver and achievement. The existence of a diligent effort and based on motivation, then someone who learns will be able to give birth to good achievements. The types of motivation consist of several parts including, namely: intrinsic and extrinsic motivation (Sardiman, 2010). 
As for the initial data collection, the number of nursing students of STIKES Panrita Husada Bulukumba level I was 45 people, level II were 53 people, and level III were 74 people. The third level students with 3 inactive statements and 1 person leave. Level IV 125 people, 1 leave and 34 people not active. In addition, in the initial data collection also obtained information related to students who get scholarships. Where at level I there were 6 people, at level II there were 7 people, level III there were 5 people, and level IV there were 5 people (Profil STIKES PHB, 2016).

Next, the initial survey related to the learning achievement of nursing students of STIKES Panrita Husada Bulukumba. It was concluded that there were still many students who received the final GPA while in the low category. Proven at level I as many as 24 people, level II general lectures as many as 20 people, block lectures as many as 6 people, and level III as many as 33 people, and level IV 19 people. In addition, each semester the average GPA of nursing students decreases (Profil STIKES PHB, 2016). Not only that, there are also some complaints during the lecture process that are obtained from interviews with students who can interfere with the learning process.

The previous research was conducted by (Astuti, 2016). The results showed there was a relationship between learning motivation and learning achievement. In line with research (Mimin, 2015). The results of this study indicate a significant relationship between intrinsic and extrinsic motivation with learning achievement. The purpose of this study was to identify whether there was a relationship between extrinsic motivation (the role of the lecturer, the condition of the learning environment, the lecturer learning method, and the supporting facilities for learning / facilities and infrastructure) with the learning achievement of the nursing student STIKES Panrita Husada Bulukumba.

\section{MATERIAL AND METHODS}

The research design used in this study is quantitative analytic with cross sectional approach (Hidayat A. A, 2014), which aims to determine the relationship of extrinsic motivation (the role of lecturers, the condition of the learning environment, lecturer learning methods, and learning support facilities or facilities and infrastructure ) with STIKES Panrita Husada Bulukumba nursing student learning achievements. According to Sugiyono in (Hidayat A. A, 2014) the population is a generalization area consisting of: objects / subjects that have certain quantities and characteristics determined by researchers to be studied and then conclusions drawn. The population in this study were nursing students of STIKES Panrita Husada Bulukumba level I, II, III, and IV as many as 
297 students. The sampling method used is: simple random sampling technique, sample selection in this way is the simplest type of probability. To achieve this sampling, each element is selected randomly (Nursalam, 2008). The number of samples in this study were 100 people. Where at level I (14 people), level II (15 people), level III (42 people), and level IV as many as (29 people).

The instrument used in this study was a questionnaire that had been tested for validity and reliability, where 40 items of the statement were declared valid. This is to see extrinsic motivation in terms of the role of the lecturer, the condition of the learning environment, the lecturer learning method, and learning support facilities/facilities and infrastructure as well as the documentation sheet to see the value of student GPA. Data were analyzed based on measuring scale and research objectives using computerized program software (SPSS 20). Data were analyzed by (a). Univariate Analysis, univariate analysis carried out analyzing each variable of the research results. (2). Bivariate analysis, analysis carried out more than two variables. Bivariate analysis functions to determine the relationship between variables (Sujarweni, 2014). The statistical test used is the Chi-square if it meets the requirements but if it does not meet the Fisher test is used as an alternative. This test aims to see whether or not there is a meaningful relationship between the observed frequency distributions and the expected significance level of 0.05 .

\section{RESULTS}

Table 1. Frequency Distribution of Respondents by Gender and Levels of Nursing Students STIKES Panrita Husada Bulukumba

\begin{tabular}{cccc}
\hline \multicolumn{2}{c}{ Responden Characteristic } & Frequenci & Percentage (\%) \\
\hline \multirow{2}{*}{ Gender } & Male & 14 & 14.0 \\
& Female & 86 & 86.0 \\
\hline \multirow{2}{*}{ Level } & Level I & 14 & 14.0 \\
& Level II & 15 & 15.0 \\
& Level III & 42 & 42.0 \\
& Level IV & 29 & 29.0 \\
\hline & Amount & $\mathbf{8 3}$ & $\mathbf{1 0 0 , 0}$ \\
\hline
\end{tabular}

In (table 1) shows that the majority of respondents are female, which is around $86.0 \%$. In addition to gender, the table also shows the level of the respondent. Where most are at level III about 42 respondents (42.0\%). 
Table 2. Frequency Distribution of Respondents Based on Extrinsic Motivation

\begin{tabular}{lcc}
\hline Extrinsic Motivation & Frequency & Percentage (\%) \\
\hline The Role of Lecturers & 92 & 92.0 \\
Ideal & 8 & 8.0 \\
Not ideal & 91 & 91.0 \\
Learning environment conditions & 9 & 9.0 \\
Conducive & & \\
Not conducive & 88 & 88.0 \\
Lecturer learning methods & 12 & 12.0 \\
Right & & \\
Not fixed & 80 & 80.0 \\
Facilities and infrastructure & 20 & 20.0 \\
Adequate & & \\
Inadequate & 83 & 83.0 \\
Learning achievement & 17 & 17.0 \\
Satisfying & 100 & 100.0 \\
Not satisfactory $\quad$ Total &
\end{tabular}

Based on (table 2) shows that in terms of the role of lecturers, most of which fall into

the ideal lecturer role category of 92 respondents (92.0\%). The extrinsic motivation in terms of the conditions of the learning environment is mostly conducive to 91 respondents (91.0\%). Most extrinsic motivation in terms of lecturer learning methods, where the selection of the right method 88 respondents (88.0\%). While the category of selecting inappropriate methods is 12 respondents (12.0\%). Furthermore extrinsic motivation in terms of facilities and infrastructure is mostly included in the adequate category of 80 respondents (80.0\%). While learning achievement, most of the students who obtained learning achievements were satisfying 83 respondents (83.0\%).

Table 3. Relationship of Extrinsic Motivation

\begin{tabular}{|c|c|c|c|c|c|c|c|}
\hline \multirow[b]{3}{*}{ Extrinsic Motivation } & \multicolumn{4}{|c|}{ Learning achievement } & & & \multirow{3}{*}{$\mathbf{P}$} \\
\hline & \multicolumn{2}{|c|}{ Satisfying } & \multicolumn{2}{|c|}{ Not satisfactory } & \multicolumn{2}{|c|}{ Amount } & \\
\hline & $\mathrm{N}$ & $\%$ & $\mathrm{n}$ & $\%$ & $\mathrm{~N}$ & $\%$ & \\
\hline The Role of Lecturers & & & & & & & 0.003 \\
\hline Ideal & 80 & 87.0 & 12 & 13.0 & 92 & 100 & \\
\hline Not ideal & 3 & 37.5 & 5 & 62.5 & 8 & 100 & \\
\hline Learning environment conditior & & & & & & & 0,043 \\
\hline Conducive & 78 & 85.7 & 13 & 14.3 & 91 & 100 & \\
\hline Not conducive & 5 & 55.6 & 4 & 44.4 & 9 & 100 & \\
\hline Lecturer learning methods & & & & & & & 0,029 \\
\hline Right & 76 & 86.4 & 12 & 13.6 & 88 & 100 & \\
\hline Not fixed & 7 & 58.3 & 5 & 41.7 & 12 & 100 & \\
\hline Facilities and infrastructure & & & & & & & 0.040 \\
\hline Adequate & 70 & 87.5 & 10 & 12.5 & 80 & 100 & \\
\hline Inadequate & 13 & 65.0 & 7 & 35.0 & 20 & 100 & \\
\hline Learning achievement & & & & & & & \\
\hline Satisfying & & & & & & & \\
\hline Not satisfactory & & & & & & & \\
\hline Amount & 83 & 83.0 & 17 & 17.0 & 100 & 100 & \\
\hline
\end{tabular}


From the results of the bivariate analysis in table 3 shows the relationship of extrinsic motivation (the role of lecturers) with learning achievement where the role of the ideal lecturer with the satisfying achievement of 80 respondents (87.0\%) is higher than the role of lecturers who are not ideal with the unsatisfactory achievement of 5 respondents (62.5\%). This shows the tendency of differences in the percentage of the role of ideal and not ideal lecturers with learning achievement. Chi-Square alternative Fisher test results obtained $\mathrm{p}=0.003(\mathrm{p}<0.05)$, then the conclusion there is a significant relationship between the role of lecturers with learning achievement.

The relationship between extrinsic motivation (the condition of the learning environment) and learning achievement, where conducive environmental conditions with satisfying achievement is more 78 respondents (85.7\%) compared to the condition of non-conducive environment with unsatisfactory achievement 4 respondents (44.4\%). This proves the tendency of differences in the percentage of conducive and nonconducive environmental conditions with learning achievement. Chi-Square alternative Fisher test results obtained $p=0.043(p<0.05)$, it can be concluded that there is a significant relationship between the conditions of the learning environment with learning achievement. Besides, table 3 also shows the relationship of extrinsic motivation (lecturer learning method) with learning achievement where most of the instructor learning methods are right with satisfactory achievement of 76 respondents $(86.4 \%)$, in contrast to the method of teaching lecturer improperly with unsatisfactory achievement of only 5 respondents (41.7\%). This indicates the tendency of differences in the percentage of instructor learning methods that are appropriate and not appropriate with learning achievement. Chi-Square alternative Fisher test results obtained $\mathrm{p}=0.029$ ( $\mathrm{p}$ $<0.05)$, then the conclusion there is a significant relationship between lecturer learning methods with learning achievement.

While the results for the relationship of extrinsic motivation (facilities and infrastructure) with learning achievement, where facilities and infrastructure are adequate with satisfying achievements more than 70 respondents (87.5\%) compared to inadequate facilities and infrastructure with unsatisfactory performance of 7 respondents (35.0\%). This proves the tendency of differences in the percentage of adequate and inadequate facilities and infrastructure with learning achievement. ChiSquare alternative Fisher's test results obtained $p=0.040(p<0.05)$, the conclusion 
there is a significant relationship between facilities and infrastructure with learning achievement.

\section{DISCUSSION}

From the data distribution of the results of the bivariate analysis using Fisher's alternative Chi-Square test, it shows that there is a significant and significant relationship between extrinsic motivation in terms of the role of the lecturer and student achievement. Evidenced by the percentage value of $p=0.003$. In line with research conducted by (Muarif, 2018) with the conclusion that there is an indirect relationship between the role of lecturers with learning achievement through learning motivation. A lecturer who is disciplined, masters the material and always guides and supports students' perception can increase their motivation. According to Salam in (Ulfah, 2011), lecturer students generally are figures who can encourage learning.

Researcher's assumptions regarding the results of the study describe that the average nursing student STIKES Panrita Husada Bulukumba has an ideal extrinsic motivation (the role of the lecturer) with satisfactory achievement. This means that the extrinsic motivation of the lecturer role is related to learning achievement. Learning achievement achieved by someone is not formed just like that. In the learning process, the role of the lecturer has an influence on learning achievement. Lecturers are facilitators, inspirators, and moderators for students. In addition to the role of the lecturer, the results of the bivariate test using Fisher's Chi-Square alternative test, related to the condition of the learning environment were also shown to have a positive and significant relationship with learning achievement. Can be proven by looking at the acquisition value of $p=0.043$. Supported by research (Ariwibowo, 2012) by showing a conclusion there is a positive and significant influence between the learning environment on the learning achievement of PPKn students in 2008/2009. The environment is one of the factors that influence learning and have an impact on student achievement. The environment is part of humans, especially for students to live and interact with each other. The conducive learning environment conditions include social environment and non-social environment (Rahmawati, 2013).

The researcher's assumption concludes that the extrinsic motivation of the conditions of the learning environment with the learning achievements of nursing students is in the good category. The condition of the learning environment is one factor that can foster student motivation in learning, where it can produce good learning 
achievements as well. Not unlike the results of the previous description by using the ChiSquare alternative Fisher test. From table 3 also proves that lecturer learning methods also have a significant or significant relationship with learning achievement. Can be seen from the value of $\mathrm{p}=0.029$ which means $<\alpha=0.05$. In accordance with research (Alam, 2016), As for the conclusion of this study partially shows that learning motivation and learning methods have a positive effect on learning achievement. According to Sudjana and Hasibuan in (Alam, 2016), learning methods are the method or approach used in presenting or delivering subject matter. Learning methods have an influence, but this needs to be seen from the selection of learning methods. Because there are some important things that need to be considered in the selection of methods. So if one of these things is not met then it will affect motivation and impact on achievement.

Researcher's assumptions related to the study describe that satisfying the learning achievement of STIKES nursing students Panrita Husada Bulukumba has a relationship with their extrinsic motivation in terms of the choice of lecturer learning methods. In the selection of learning methods, there are some important things to note, namely: the intrunksional objectives of the lesson, time and facilities, student's initial knowledge. Results from table 3 using Fisher's Chi-Square alternative test showed similarities with the role of lecturers and the conditions of the learning environment. Facilities and infrastructure also have a significant relationship with student learning achievement. Supported by the percentage value of $p=0.040$ smaller than the value of $\alpha$.

In line with research (Sriyono, 2017) the conclusion of his research shows that there is a significant relationship between educational facilities and infrastructure with learning achievement. According to (Ermiza, 2017) stated that complete and adequate facilities and infrastructure is one of the efforts to increase learning motivation in the learning process. Not only in terms of benches or chairs, but also in terms of adequate campus environmental infrastructure.

The researchers' assumptions describe that the facilities and infrastructure are related to student learning achievements. In other words, the more adequate extrinsic motivation in terms of facilities and infrastructure the more satisfying learning achievement obtained by students. Incomplete facilities and infrastructure will disrupt the learning process. That is because facilities and infrastructure are one of the efforts to increase motivation in the learning process. 


\section{CONCLUSION}

Based on the results of research and data processing, it can be concluded that there is a significant or significant relationship between extrinsic motivation (the role of the lecturer, the condition of the learning environment, lecturer learning methods, and learning support facilities / infrastructure) and the learning achievements of STIKES nursing students Panrita Husada Bulukumba. It is expected that the results of this study can be used as information or reference for students and management of the STIKES Panrita Husada Bulukumba campus.

\section{DAFTAR PUSTAKA}

Abbas, N. A. (2017). Pengaruh Metode Reward Dan Punishmant Terhadap Motivasi Belajar Siswa Pada Mata Pelajaran Sejarah Kelas XI IPS SMA 1 KALIANDA Tahun Ajaran 2016/2017. 14-16.

Afrianti, V. (2014). Hubungan Peran Pembimbing Akademik Dengan Motivasi Belajar Mahasiswa

DIII Kebidanan Semester IV Stikes Aisyiyah Yogyakarta. Aisyiyah, 5.

Agata, A. K. (2016). Gambaran Faktor-Faktor Yang Mempengaruhi Motivasi Belajar Mahasiswa Program Studi Ilmu Keperawatan Universitas Diponegoro Semarang. Keperawatan, 38.

Aiyub. (2015). Motivasi Belajar Mahasiswa Selama Mengikuti Pendidikan Tinggi Keperawatan. Idea Nursing Journal, 87.

Alam, A. M. (2016). Pengaruh Motivasi Belajar Dan Metode Pembelajaran Terhadap Prestasi Belajar Mahasiswa Program Studi Komputerisasi Akuntasi Politeknik LP31 Jakarta Kampus Blok M. BIJAK, 104.

Aliah, N. (2013). Faktor-Faktor Yang Mempengaruhi Motivasi Belajar Mahasiswa Diploma Kebidanan STIKES U'Budiyah Sigli. Jurnal Kesehatan, 9-12.

Ariwibowo, M. S. (2012). Pengaruh Lingkungan Belajar terhadap Prestasi Belajar Mahasiswa PPKn Angkatan 2008/2009 Universitas Ahmad Dahlan Semester Ganjil Tahun Akademik 2010/2011. Citizenship, 1.

Asmadi. (2008). Konsep Dasar Keperawatan. Jakarta: EGC.

Astuti, E. (2016). Hubungan Motivasi Belajar Dengan Prestasi Belajar Pada Mahasiswa S1 Keperawatan Di STIKES William Booth Surabaya. Ejurnal Keperawatan, 1.

B. Uno, H. (2010). Teori Motivasi \& Pengukurannya. Jakarta: Bumi Aksara.

Bahri, S. (2011). Psikologi Belajar. Jakarta: PT.Rineka Cipta.

Darmadi, H. (2017). Pengembangan Model dan Metode Pembelajaran dalam Dinamika Belajar Siswa. Yogyakarta: Deepublish. 
Efriana, C. (2012). Faktor-Faktor Yang Berubungan Dengan Prestasi Belajar Mahasiswi Tingkat III Program Studi Diploma III Kebidanan STIKes U’Budiyah Banda Aceh . Jurnal IImiah STIKES U'Budiyah, 12.

Ermiza. (2017). Faktor-Faktor Yang Berhubungan Dengan Motivasi Belajar Mahasiswa Semester VI Di Program Studi DIII Kebidanan STIKES Fort De Kock Bukittinggi Tahun 2013. Maternity And Neonatal, 184.

Hakim, M. A. (2015). Analisis Faktor-Faktor Yang Mempengaruhi Prestasi Belajar IPS Siswa Kelas V Di MIN Bitung Jawa. UIN Syarif Hidayatullah Jakarta, 77-83.

Hidayat, A. A. (2014). Metode Penelitian Keperawatan dan Teknik Analisis Data. Jakarta: Salemba Medika.

Islamiati, R. (2016). Hubungan Antara Motivasi Ekstrinsik Siswa Dengan Prestasi Belajar Siswa Kelas V SD Se-Gugus I Kecamatan Tualang Perawang. FKIP Riau, 2.

Jaali, H. (2009). Psikologi Pendidikan. Jakarta: Bumi Aksara.

Kania, I. (2014). Hubungan Faktor Ekstern Terhadap Prestasi Belajar Mahasiswa Tingkat Iii Prodi DIII Kebidanan Stikes Medika Cikarang Tahun 2013/2014 . Jurnal Ilmiah Kebidanan STIKes Medika Cikarang, 1.

Malasari, R. B. (2017). Hubungan Lingkungan dan Motivasi Belajar dengan Prestasi Belajar Mahasiswa Akademi Kebidanan Berlian Nusantara Magetan. IJMS, 171.

Martono, S., \& Sulistiowati. (2016). Analisis Faktor-Faktor Yang Mempengaruhi Motivasi Belajar Mahasiswa. STIKOM Surabaya, 5-6.

Meliala, E. (2014). Faktor-Faktor Yang Mempengaruhi Motivasi Belajar Pada Mahasiswa S1 Keperawatan Semester VII Di STIKES Sumatera Utara Medan Tahun 2014. STIKES SU, 44-68.

Mendari, A. S., \& Kewal, S. S. (2015). Motivasi Belajar Pada Mahasiswa. Jurnal Pendidikan Akuntansi Indonesia, 8.

Mimin, P. (2015). Hubungan Motivasi Intrinsik Dan Ekstrinsik Mahasiswa DIII Kebidanan Pelita Andalas Dengan Prestasi Belajar Di Akademi Kebidanan Pelita Andalas Bukittinggi Tahun 2015 . E-journals Repository, 2.

Muarif, S. (2018). Hubungan Peranan Dosen Di Kelas, Iklim Kelas, Dan Motivasi Belajar Terhadap Prestasi Belajar Mahasiswa Prodi PAUD IKIP PGRI JEMBER . EFEKTOR ISSN, 8-9.

Nasution, S. I. (2017). analisis Faktor-Faktor Yang Berpengaruh Terhadap Motivasi Berprestasi Mahasiswa Prodi Manajemen Pendidikan Islam Fakultas Tarbiyah Dan Keguruan UIN Raden Intan Lampung. Al-Idarah, 42-43.

Nursalam. (2008). Konsep Dan Penerapan Metodologi Penelitian Ilmu Keperawatan . Jakarta: Salemba Medika.

Persiyona, M. (2015). Hubungan Motivasi Intrinsik Dan Ektrinsik Mahasiswa DIII Kebidanan Pelita Andalas Dengan Prestasi Belajar Di Akademi Kebidanan Pelita Andalas Bukittinggi Tahun 2015. https://repository.fdk.ac.id, 1.

Profil STIKES PHB. (2016). Transkrip Nilai. Bulukumba: Stikespanritahusada.ac.id. 
Rahmawati, R. R. (2013). Hubungan Fasilitas Belajar Dan Lingkungan Belajar Dengan Prestasi Belajar Mata Pelajaran Sosiologi Siswa Kelas XI IPS Sma Negeri 3 Sukoharjo Tahun Ajaran 2012/2013 . FKIP Sebelas Maret, 3.

Ristekdikti. (2016). Standar Nasional Pendidikan Tinggi Berdasarkan Permenristekdikti RI Nomor 44 Tahun 2015.

Rozaqoh, L. (2008). Hubungan Antara Dukungan Orang Tua Dengan Motivasi Belajar Remaja. Journal Psikosains, 63-69.

Sardiman. (2010). Interaksi dan Motivasi Belajar-Mengajar. Jakarta: Rajawali Pers.

Sari, E., \& Sedin, Y. (2013). Faktor Dominan Yang Mempengaruhi Prestasi Belajar Mahasiswa Di Akademi Keperawatan William Booth Surabaya. AKPER William Surabaya, 5.

Simamora, R. H. (2009). Buku Ajar Pendidikan dalam Keperawatan. Jakarta: EGC.

Sriyono, E. (2017). Hubungan Sarana Dan Prasarana Pendidikan Dengan Prestasi Belajar Siswa Kelas Viii Di Smpn 10 Kota Jambi . http://repository.unja.ac.id/id/eprint/3101,1-2.

Suarli, S., \& Bahtiar, Y. (n.d.). Manajemen Keperawatan dengan Pendekatan Praktis. Jakarta: Erlangga.

Sugiyono. (2012). Statistika Untuk Penelitian. Bandung: Alfa Beta.

Sujarweni, V. (2014). Metodologi Penelitian Keperawatan. Yogyakarta: Gava Media.

Swarjan, I. K. (2015). Metodologi Penelitian Kesehatan (Edisi Revisi). Yogyakarta: ANDI.

Ulfah, H. R. (2011). Hubungan Antara Persepsi Mahasiswa Terhadap Dosen Dengan Motivasi Belajar Di Program Studi Keperawatan Universitas Muhammadiyah Surakarta. Publikasih Ilmiah, 2.

Undang-Undang RI. (2008). Nomor 20 Tahun 2003 tentang Sistem Pendidikan Nasional. Walgitu, B. (2010). Bimbingan Dan Konseling. Yogyakarta: CV. Andi Offset.

Wasis. (2008). Pedoman Riset Praktis Untuk Profesi Perawat. Jakarta: EGC.

Yuzarion. (2017). Faktor Yang Mempengaruhi Prestasi Belajar Peserta Didik. IImu Pendidikan, 111-112. 